\title{
Newly Isolated Penicillium sp. for Cellulolytic Enzyme Production in Soybean Hull Residue
}

\section{Ludmila Noskoski Salazar ${ }^{1}$}

https://orcid.org/0000-0002-2981-4898

Viviane Astolfi ${ }^{1}$

https://orcid.org/0000-0002-9912-9618

Tailan Antonio Ogimbosvski ${ }^{1}$

https://orcid.org/0000-0002-7465-0394

Naionara Ariete Daronch ${ }^{1}$

https://orcid.org/0000-0002-3270-3275

\author{
Jamile Zeni ${ }^{1}$ \\ https://orcid.org/0000-0002-0529-2212
}

Alexander Junges ${ }^{1}$

https://orcid.org/0000-0001-7666-264X

\author{
Rogério Luis Cansian 1 \\ https://orcid.org/0000-0002-1857-9036 \\ Geciane Toniazzo Backes ${ }^{1 \star}$ \\ https://orcid.org/0000-0001-8652-8399
}

${ }^{1}$ Regional Integrated University of Alto Uruguay and the Missions, Department of Food Engineering, Erechim, Rio Grande do Sul, Brazil

Received: 2017.11.06; Accepted: 2020.02.21

*Correspondence: gtoniazzo@uricer.edu.br; Tel.: +55-54-35209000, Department of Food Engineering, Universidade Regional Integrada do Alto Uruguai e das Missões (URI), Av. Sete de Setembro, 1621 - Erechim, RS - Brazil - CEP: 99709-910.

\section{HIGHLIGHTS}

- Xylanase and avicelase produced by Penicillium sp.

- Temperature and agitation in the extraction process influence enzyme activity. Avicelase was more stable at thermal deactivation than xylanase.

- The using alternative substrates is a way to reduce costs production of cellulases.

Abstract: (1) Background: The aim of this study was to evaluate the production and partial characterization of xylanase and avicelase by a newly isolated Penicillium sp. in solid-state fermentation, using soybean hulls as substrate. (2) Methods: Temperature, time, number of spores, and substrate moisture on xylanase and avicelase bioproduction were evaluated, maximizing activity with $30^{\circ} \mathrm{C}, 1 \times 10^{6}$ spores $/ \mathrm{g}$ substrate, 14 and 7 days of fermentation with 70 and $76 \%$ substrate moisture contents, for xylanase and avicelase, respectively. (3) Results: Different solvents, temperatures, and agitation in the enzymatic extraction were evaluated, obtaining higher activities, 430.77 and $26.77 \mathrm{U} / \mathrm{g}$ for xylanase and avicelase using $30 \mathrm{~min}$ extraction and $0.05 \mathrm{M}$ citrate buffer solution $(\mathrm{pH} 4.5)$, respectively at $60^{\circ} \mathrm{C}$ and $175 \mathrm{rpm}$ and $50^{\circ} \mathrm{C}$ and 125 rpm. The optimum $\mathrm{pH}$ and temperature for enzymatic activity determination were 5.3 and $50^{\circ} \mathrm{C}$. Enzyme extract stability was evaluated, obtaining higher stability with $\mathrm{pH}$ between 4.5 and 5.5 , higher temperature of up to $40^{\circ} \mathrm{C}$. The kinetic thermal denaturation $\left(\mathrm{K}_{\mathrm{d}}\right)$, half-life time, D-value, and Z-value were similar for both enzymes. The xylanase Ed value $(89.1 \mathrm{~kJ} / \mathrm{mol})$ was slightly lower than the avicelase one $(96.7$ $\mathrm{kJ} / \mathrm{mol}$ ), indicating higher thermostability for avicelase. (4) Conclusion: In this way, the production of cellulases using alternative substrates is a way to reduce production costs, since they represent about $10 \%$ of the world demand of enzymes, with application in animal feed processing, food production and 
breweries, textile processing, detergent and laundry production, pulp manufacturing and the production of biofuels.

Keywords: Xylanase; avicelase; solid-state fermentation; partial characterization; enzymatic thermostability.

\section{INTRODUCTION}

Cellulases are a complex system consisting of three enzymes that act synergistically to hydrolyze the cellulose system, breaking down the $\beta(1 \rightarrow 4)$ cellulose glycosidic links [1,2]. These enzymes are produced by various microorganisms such as Aspergillus, Cladosporium, Fusarium, Penicillium and Trichoderma species [3].

Xylanases, also referred to as endo-1,4- $\beta$-xylanase and $\beta-1,4-D-x y l a n$ hydrolases (EC 3.2.1.8), are the main enzymes involved in xylan degradation, reducing the polymerization degree of the substrate. The sites selected for xylan substrate hydrolysis depend on its nature, chain length, branching degree and number of substituents [4,5]. Xylanase induction in filamentous fungi is a complex phenomenon, and the response level varies for each microorganism. A substrate that induces xylanase production in one species might be a production inhibitor on another species [6]. Xylanases are of great interest, since xylan is the most abundant renewable source of carbon, after cellulose, it is found in wood and agricultural waste and is the main polysaccharide component of hemicellulose $[7,8]$.

There are two types of exoglucanases, 1,4- $\beta$-D-glucan cellobiohydrolase (EC 3.2.1.91) or avicelase, and 1,4- $\beta$-D-glucan glucohydrolase (EC 3.2.1.74) that remove respectively cellobiose units and glucose units, both acting from the non-reducing ends of oligosaccharides produced by endoglucanase action. The term "Avicelase" is commonly regarded as synonymous with exoglucanase or cellobiohydrolase [9]. Since exoglucanase is normally found to be synthesized along with two other cellulases types, it is also important to estimate the relative ability of a particular cellulase-producing strain on exoglucanase release and the parameters affecting the synthesis [10].

Avicelases are found to have potential applications in agricultural waste materials bioconversion in to useful products such as fuels and animal feed. Among cellulases, the exoglucanases appear to catalyze most bond-cleavages in the saccharification of crystalline cellulose and is one of the most abundant components in cellulase preparation, especially fungus-derived commercial enzymes. Although a number of microorganisms were reported to produce cellulases, in comparison to that of endoglucanase and betaglucosidase, reports on exoglucanase or avicelase production are remarkably scarce [11].

The cellulolytic enzyme market is the third largest in the world in production volume due to its numerous applications such as textiles, paper recycling, extraction and juices preparation, and on the use of biodegradable detergents enzymatic agents as an additive in animal feed. Cellulases production may prove to be the first in production volume for new procedures with lower energy and maintenance costs and a selection of economically and technologically viable microorganisms; it remains a current research topic, with several recent studies [2,12-14].

Thus, this study aimed at evaluating the production and partial characterization of xylanase and avicelase from a new isolated from Penicillium sp., in solid-state fermentation using soybean hulls residue.

\section{MATERIAL AND METHODS}

\section{Bioproduction}

The microorganism used in this study was isolated, qualitatively selected, and identified as Penicillium sp. by Bortoli and coauthors [15].

Initially, assays were carried out in order to evaluate time and temperature influence on cellulolytic enzymes bioproduction by the isolated fungus, with the enzyme activity analyzed at 3 days intervals for up to 21 days at temperatures ranging from 20 to $35^{\circ} \mathrm{C}$, using soybean hulls as a substrate with $70 \%$ humidity and a $10^{7}$ spores/g substrate inoculum. The substrate mixture was sterilized in a vertical downward autoclave (Phoenix, model AV75) at $121^{\circ} \mathrm{C}$ and $1 \mathrm{~atm}$ for $15 \mathrm{~min}$. A spores concentration was inoculated in to the mixture and later incubated in a germination chamber (Tecnal, Piracicaba, Brazil; model TE401).The extraction conditions were $50^{\circ} \mathrm{C}$ and $100 \mathrm{rpm}$ for $30 \mathrm{~min}$, using citrate buffer $(0.05 \mathrm{M}$ and $\mathrm{pH} 4.8)$ [16].

After defined bioproduction time and temperature, the influence of the number of spores (4.6 to 7.4 Log spores/g wet substrate), and the substrate moisture contents

(34-76\%) on xylanase and avicelase 
production were evaluated using a $2^{2}$ full factorial design (Table 1). The dependent variable was the enzyme activity $(\mathrm{U} / \mathrm{g})$. Agitation, temperature, and extraction time were kept constant $\left(100 \mathrm{rpm}, 50^{\circ} \mathrm{C}\right.$ and $30 \mathrm{~min}$, respectively). The volume of added water was measured using mass balance calculation, discounting the initial moisture of the mixture and the spores suspension. Moisture was determined by drying at $105^{\circ} \mathrm{C}$ until the substrate (soybean hulls) reached a constant weight. The water activity was determined using the AquaLab apparatus (AquaLab, model CX-2), whose operation is based on fast response hygrometers.

\section{Cellulolytic Enzymes Extraction}

Different solvents were tested, including distilled water, $1 \% \mathrm{NaCl}$, sodium citrate buffer $(0.05 \mathrm{M}, \mathrm{pH}$ 4.8), sodium acetate buffer $(0.1 \mathrm{M} \mathrm{pH} 5.0)$, and Tween $80(0.1 \% \mathrm{v} / \mathrm{v})$ for cellulolytic enzymes extraction. The extraction was conducted with $50 \mathrm{ml}$ solvent and $3.33 \mathrm{~g}$ fermented substrate, stirred at $100 \mathrm{rpm}, 50^{\circ} \mathrm{C}$, for $30 \mathrm{~min}[16,17]$. The enzymatic extract was separated from both the mycelium and the solid medium by filtration process, followed by centrifugation (MPW Med. Instruments; Model 351R) at 4,000 rpm, $4^{\circ} \mathrm{C}$, for $15 \mathrm{~min}$.

The influence of temperature $\left(35.9\right.$ to $\left.64.1^{\circ} \mathrm{C}\right)$ and agitation $(54.5$ to $195.5 \mathrm{rpm})$ on the extraction process was evaluated using a $2^{2}$ full factorial design, with the enzyme activity measurement $(\mathrm{U} / \mathrm{g})(\mathrm{Table}$ 2). The other variables were kept fixed.

\section{Partial Cellulolytic Extracts Characterization}

The $\mathrm{pH}$ (3.9 to 6.7) and temperature $\left(36\right.$ to $64^{\circ} \mathrm{C}$ ) used for xylanase and avicelase activity determination were evaluated by a $2^{2}$ full factorial design (Table 4). $0.05 \mathrm{M} \mathrm{Tris-HCl}$ and $0.01 \mathrm{M} \mathrm{NaOH}$ buffer solutions were employed for $\mathrm{pH}$ adjustment.

Enzyme extracts were submitted to different temperatures $\left(-20,4,25,40,50,60\right.$ and $\left.70^{\circ} \mathrm{C}\right)$ at $\mathrm{pH} 4.8$ to determine their stability. Stability at different $\mathrm{pH}$ values $(3.5,4.5,5.5$ and 6.5$)$ was evaluated at $25^{\circ} \mathrm{C}$. The samples were collected periodically to evaluate the enzymatic activity. Thermal and $\mathrm{pH}$ stabilities were expressed in residual enzymatic activity (\%).

Half-life time $\left(\mathrm{t}_{1 / 2}\right)$, thermal denaturation rate constant $(\mathrm{Kd})$, and the $\mathrm{D}$ value were determined at 25,40 , 50,60 and $70^{\circ} \mathrm{C}$ (Table 4).

The influence of temperature on the enzymatic inactivation constant rate $(\mathrm{Kd})$ is in accordance with the Arrhenius equation $\left(K d=A e^{E d / R T}\right)$, and its linearization $\quad\{\ln (K d)=\ln (A)-E d / R T\}$. Ed and $A$ parameters were estimated from the inclination and angular coefficient, where $A$ is pre-exponential Arrhenius constant, Ed is enzymatic denaturation activation energy, $R$ is universal constant of gases $\left(8,314 \times 10^{-3} \mathrm{~kJ} / \mathrm{mol} . \mathrm{K}\right)$ and $\mathrm{T}$ is absolute temperature $(\mathrm{K})$.

Half-life $\left(t_{1 / 2}\right)\left(t 1_{/ 2}=0,693 / K d\right)$ and decimal reduction value (D) $\{D=\ln (10) / K d\}$, correspond to the time required for a $50 \%$ reduction in initial activity at a given temperature and $10 \%$ reduction in the initial value reaction rate. The $Z$ value, specified as the variation in temperature required for $D$ value to undergo one log cycle reduction, was estimated by the angular coefficient inverse of the linear correlation of log (D) versus temperature $\left({ }^{\circ} \mathrm{C}\right)$.

\section{Xylanase and Avicelase Determination}

Xylanase activity was determined by the reducing sugar release in a $1 \%$ xylan obtained from birchwood (Sigma) in a $0.05 \mathrm{M}$ sodium citrate buffer, $\mathrm{pH} 5.3$, at $50^{\circ} \mathrm{C}$ [13]. The released reducing sugars were determined by the dinitrosalicylic acid method according to Miller [18] using 5.0 to $0.1 \mathrm{mg} / \mathrm{mL}$ xylose concentrations for the standard curve construction. An enzyme activity unit (U) was defined as the amount of enzyme capable of releasing $1 \mu \mathrm{mol}$ reducing sugar per minute (expressed as xylose equivalent), at $50^{\circ} \mathrm{C}$.

Avicelase activity (EC 3.2.1.91) consisted of adding $1 \mathrm{~mL}$ crude enzyme extract to $1 \mathrm{~mL}$ of $1 \%$ microcrystalline cellulose solution (Avicel) in $0.05 \mathrm{M}$ acetate buffer, $\mathrm{pH} 5.0$ and incubated at $50^{\circ} \mathrm{C}$ for 30 min under periodic agitation [19]. The released reducing sugars were determined by the dinitrosalicylic acid method according to Miller [18] and one unit $(U)$ of activity was defined as $1 \mu$ mol of glucose equivalent released per minute under the conditions described above, using a glucose standard curve. Appropriate controls were conducted in parallel with all assays. 
The final enzyme activities for xylanase and avicelase were expressed in enzyme production per gram of dry substrate $\left(U / g=\frac{\text { [enzyme] } \times V_{\text {buffer }}}{M}\right)$, where $\quad$ (enzyme) $=$ enzyme activity $(\mathrm{U} / \mathrm{mL}) ; \mathrm{V}_{\text {buffer }}=$ buffer volume in the extraction $(\mathrm{mL}) ; \quad \mathrm{M}=$ dry substrate mass $(\mathrm{g})$.

\section{Statistical Analysis}

The results of time and temperature influence on enzyme production and of different solvents for enzymes extraction (in triplicate) were statistically processed by analysis of variance (ANOVA) and the differences in average were compared by Tukey test (95\% confidence) using Statistica software (Statsoft version 5.0). The results obtained in the factorial design were statistically analyzed according to the experimental design methodology, using the same software.

\section{RESULTS AND DISCUSSION}

\section{Bioproduction}

The enzymatic activity results as a function of bioproduction time (Fig. 1a) presented maximum activity at 14 and 7 fermentation days respectively for xylanase and avicelase, and such periods were maintained for the other experiments.
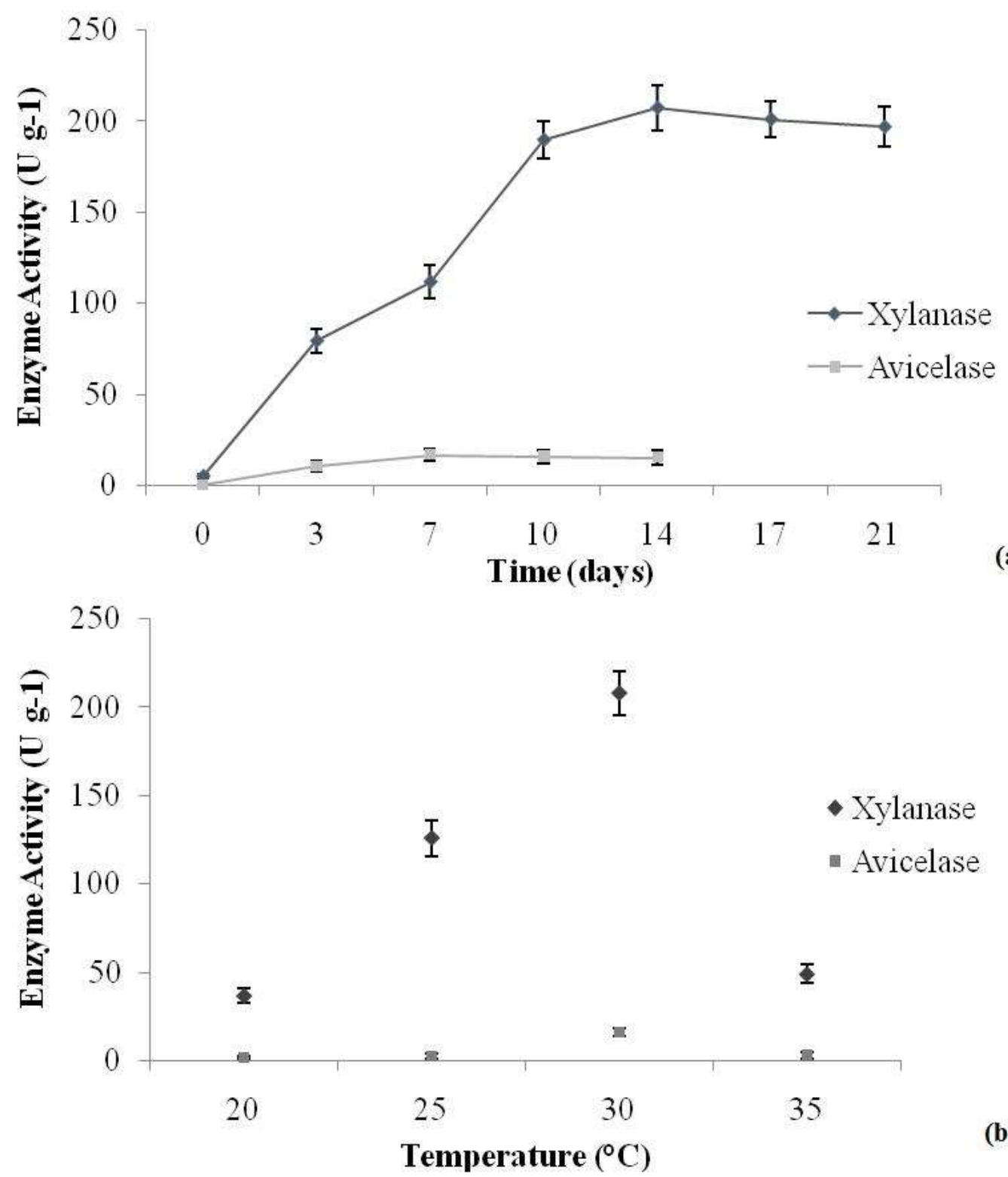

(a)

Figure 1. (a) Time and fermentation temperature (b) influence on xylanase and avicelase production. 
The optimum fermentation temperature was $30^{\circ} \mathrm{C}$ (Fig. 1b) for both xylanase and avicelase, and it had the greatest influence on xylanase activity. Similar temperature results were obtained by Kim coauthors [20] and Deswal coauthors [21] with Penicillium sp. and Fomitopsis sp. However, the required fermentation period was higher than that obtained by Ghoshal and coauthors [22].

After estabilishing ideal temperature and time for bioproduction, the influence of spores concentration and substrate moisture content (soybean hulls) on xylanase and avicelase bioproduction by the isolated Penicillium sp. (Table 1) was investigated.

Table 1. $2^{2}$ full factorial design matrix of spore concentration and fermentation moisture (real and coded values) on xylanase and avicelase production.

\begin{tabular}{|c|c|c|c|c|}
\hline \multirow{2}{*}{ Assays } & \multicolumn{2}{|c|}{ Independent Variables } & \multirow{2}{*}{$\begin{array}{c}\text { Xylanase } \\
(\mathrm{U} / \mathrm{g})\end{array}$} & \multirow{2}{*}{$\begin{array}{c}\text { Avicelase } \\
(\mathrm{U} / \mathrm{g})\end{array}$} \\
\hline & $\mathrm{X}_{1}$ & $X_{2}$ & & \\
\hline 1 & $-1(5)$ & $-1(40)$ & 36.76 & 11.52 \\
\hline 2 & $1(7)$ & $-1(40)$ & 35.48 & 13.43 \\
\hline 3 & $-1(5)$ & 1 (70) & 416.58 & 21.93 \\
\hline 4 & $1(7)$ & $1(70)$ & 435.35 & 23.73 \\
\hline 5 & $-1.41(4.6)$ & $0(55)$ & 128.97 & 12.65 \\
\hline 6 & $1.41(7.4)$ & $0(55)$ & 220.86 & 10.91 \\
\hline 7 & $0(6)$ & $-1.41(34)$ & 21.62 & 8.85 \\
\hline 8 & $0(6)$ & $1.41(76)$ & 220.00 & 21.99 \\
\hline 9 & $0(6)$ & $0(55)$ & 210.00 & 10.71 \\
\hline 10 & $0(6)$ & $0(55)$ & 224.42 & 11.17 \\
\hline 11 & $0(6)$ & $0(55)$ & 222.02 & 10.85 \\
\hline
\end{tabular}

$\mathrm{X}_{1}$ : Spore concentration (Log); $\mathrm{X}_{2}$ : Humidity (\%); Fixed independent variables: $10 \mathrm{~g}$ of soybean hull, $30^{\circ} \mathrm{C}$. Humidity and water activity correspondence: $34 \%=0.9440( \pm 0.0008) ; 40 \%=0.9488( \pm 0.0006) ; 55 \%=0.9557$ $( \pm 0.0004) ; 70 \%=0.9576( \pm 0.0016) ; 76 \%=0.9586( \pm 0.0004)$

The highest yields of xylanase (416.58 to $435.35 \mathrm{U} / \mathrm{g}$ ) occurred at $70 \%$ moisture, independent of spore concentration (5 - 7 log spores). The highest avicellase production (21.93 to $23.73 \mathrm{U} / \mathrm{g}$ ) occurred at the highest moisture content (70 and $76 \%$ ), in the same spore concentration range, showing that the moisture variable has the greatest influence on the bioproduction of these enzymes.

Equations 1 and 2 show the second order coded models that describe xylanase (14 days) and avicelase ( 7 days) activities as a function of the spores concentration and humidity within the studied ranges. For xylanase, linear spore concentration and linear moisture had a significant $(p<0.05)$ positive influence. The models were validated using analysis of variance. 0.87 and 0.93 correlation coefficients and 1.71 and $3.61 \mathrm{~F}$ values for xylanase and avicelase were obtained, respectively.

$$
\begin{aligned}
& \text { Xylanase }(\mathrm{U} / \mathrm{g})=218.48+18 \cdot 44 \cdot \mathrm{X}_{1}+132 \cdot 82 \cdot \mathrm{X}_{2}-28 \cdot 10 \cdot \mathrm{X}_{2}{ }^{2} \\
& \text { Avicelase }(\mathrm{U} / \mathrm{g})=10 \cdot 90+1.46 \cdot \mathrm{X}_{1}{ }^{2}+4 \cdot 92 \cdot \mathrm{X}_{2}+3 \cdot 29 \cdot \mathrm{X}_{2}{ }^{2}
\end{aligned}
$$

Where: $\mathrm{X}_{1}=$ Spores concentration (Log); $\mathrm{X}_{2}=$ Humidity (\%).

The definition of optimal conditions for production of avicellase and xylanase, such as time, temperature, spore concentration and humidity, are important due to the characteristic specificity of each microorganism and substrate used. In this way, the literature presents results different from those of the present study, being these ones for each enzyme, microorganism and production condition. Astolfi [23], using the same substrate as the one in the present study, obtained $1130.7 \mathrm{U} / \mathrm{g}$ on the sixth fermentation day using Trichoderma reesei NRRL 3652 with soybean husk moisture at 70\% and $10^{6} \mathrm{spores} / \mathrm{g}$. Pirota coauthors [24] using wheat bran as a substrate and Aspergillus niger (P6B2 isolate) obtained 1076.9 U/g enzymatic activity for xylanase at $35^{\circ} \mathrm{C}, 10^{7}$ spores $/ \mathrm{g}$, and $60 \%$ substrate moisture after $72 \mathrm{~h}$ fermentation. Mamma and coauthors [25] using orange peel substrates, obtained 77.1 and $37.8 \mathrm{U} / \mathrm{g}$ maximum activities with $A$. niger and Penicillium decumbens, at $90 \%$ humidity, $2.3 \times 10^{7} \mathrm{spores} / \mathrm{g}$, for 10 cultivation days. The enzymatic activity values for xylanase reported in this work are intermediate compared to other studies found in the literature, though with a maximum activity in 14 days of culture.

Despite there are only a few studies reporting avicelase activity obtained from fungal isolates, the avicelase activities obtained from isolated fungus Penicillium sp. were high $(23.7 \mathrm{U} / \mathrm{g})$. Pereira and 
coauthors [26] reported a $3.6 \mathrm{U} / \mathrm{g}$ activity for avicelase obtained from Myceliophthora thermophila JCP 1-4 fungus, from 55 to $70^{\circ} \mathrm{C}$. Kuo et al., [27] obtained $0.2 \mathrm{U} / \mathrm{mL}$ with improved avicelase activity from the isolated Meyerozyma caribica cultivated at $25-27^{\circ} \mathrm{C}$, for 6 days.

\section{Cellulolytic Enzymes Extraction}

Different solvents were tested for the enzymatic extraction process (distilled water; $\mathrm{NaCl} 1 \%$; sodium citrate buffer $(0.05 \mathrm{M}, \mathrm{pH} 4.5)$; sodium acetate buffer $(0.2 \mathrm{M}, \mathrm{pH} 5.5)$ and tween $80,0.1 \%, \mathrm{v} / \mathrm{v})$. The higher enzyme activities were achieved using sodium citrate buffer $(0.05 \mathrm{M}, \mathrm{pH} 4.5), 176.54$ and $14.22 \mathrm{U} / \mathrm{g}$ for xylanase and avicelase, respectively. No statistical differences were observed between sodium acetate and tween 80 buffers for avicelase extraction. But differing statistically from the other solvents for xylanase extraction. Followed by a $0.2 \mathrm{M}$ sodium acetate buffer $\mathrm{pH} 5.5$ and tween $800.1 \%(\mathrm{v} / \mathrm{v})$, in which 129.69 and $116.52 \mathrm{U} / \mathrm{g}$ and 15.17 and $15.03 \mathrm{U} / \mathrm{g}$ were obtained for xylanase and avicelase activities, respectively. $\mathrm{NaCl}$ and distilled water showed the low extraction capacity for these enzymes, 98.83 and $46.65 \mathrm{U} / \mathrm{g}$ and 1.91 and $2.65 \mathrm{U} / \mathrm{g}$ for xylanase and avicelase, respectively. From the results, $0.05 \mathrm{M}$ sodium citrate buffer, $\mathrm{pH}$ 4.5 was defined as the extraction solvent for the subsequent tests. Corroborating with the results obtained in the present study, Dhillon coauthors [16] obtained better FPase, Cmcase, and xylanase extractions with citrate buffer at $\mathrm{pH} 4.8$.

The influence of both temperature and agitation on enzyme extraction process was evaluated through a complete $2^{2}$ factorial design (Table 2). The maximum activities for xylanase and avicelase were 430.77 and $26.77 \mathrm{U} / \mathrm{g}$, at $60^{\circ} \mathrm{C}$ and $175 \mathrm{rpm}$ and $50^{\circ} \mathrm{C}$ and $125 \mathrm{rpm}$, respectively.

Table 2. $2^{2}$ full factorial design matrix of temperature and agitation influence on xylanase and avicelase extraction.

\begin{tabular}{|c|c|c|c|c|}
\hline \multirow{2}{*}{ Assays } & \multicolumn{2}{|c|}{ Independent Variables } & \multirow{2}{*}{$\begin{array}{c}\text { Xylanase } \\
(\mathrm{U} / \mathrm{g})\end{array}$} & \multirow{2}{*}{$\begin{array}{c}\text { Avicelase } \\
(\mathrm{U} / \mathrm{g})\end{array}$} \\
\hline & $\mathrm{X}_{1}$ & $X_{2}$ & & \\
\hline 1 & $-1(40)$ & $-1(75)$ & 283.63 & 5.62 \\
\hline 2 & $1(40)$ & $-1(175)$ & 280.48 & 4.03 \\
\hline 3 & $-1(60)$ & $1(75)$ & 309.54 & 3.25 \\
\hline 4 & $1(60)$ & $1(175)$ & 430.77 & 5.44 \\
\hline 5 & $-1.41(35.9)$ & $0(125)$ & 350.46 & 3.8 \\
\hline 6 & $1.41(64.1)$ & $0(125)$ & 370.01 & 4.57 \\
\hline 7 & $0(50)$ & $-1.41(54.5)$ & 151.6 & 0.4 \\
\hline 8 & $0(50)$ & $1.41(195.5)$ & 272.62 & 5.72 \\
\hline 9 & $0(50)$ & $0(125)$ & 282.93 & 26.77 \\
\hline 10 & $0(50)$ & $0(125)$ & 267.65 & 24.15 \\
\hline 11 & $0(50)$ & $0(125)$ & 252.36 & 25.55 \\
\hline
\end{tabular}

$\mathrm{X}_{1}=$ Temperature $\left({ }^{\circ} \mathrm{C}\right) ; \mathrm{X}_{2}=$ Agitation $(\mathrm{rpm})$.

For xylanase activity, statistically treated results showed a significant positive effect $(p<0.05)$ for temperature (linear and quadratic) and agitation (linear) variables, indicating an increase in temperature and/or agitation on extraction solution would probably increase xylanase activity (Fig. 2). For avicelase, Equation 3 elaborated from the statistical treatment of results, presented the second order coded model as a function of temperature and agitation extraction, within the studied ranges, with 0.99 correlation coefficients and $37.6 \mathrm{~F}$ values. The maximum activity was obtained at $50^{\circ} \mathrm{C}$ and $125 \mathrm{rpm}$, referring to the experimental planning central point assays.

Avicelase $(\mathrm{U} / \mathrm{g})=25.49-10.44 . \mathrm{X}_{1}^{2}-11.01 . \mathrm{X}_{2}^{2}$

Where: $\mathrm{X}_{1}$ : Temperature $\left({ }^{\circ} \mathrm{C}\right) ; \mathrm{X}_{2}=$ Agitation (rpm). 


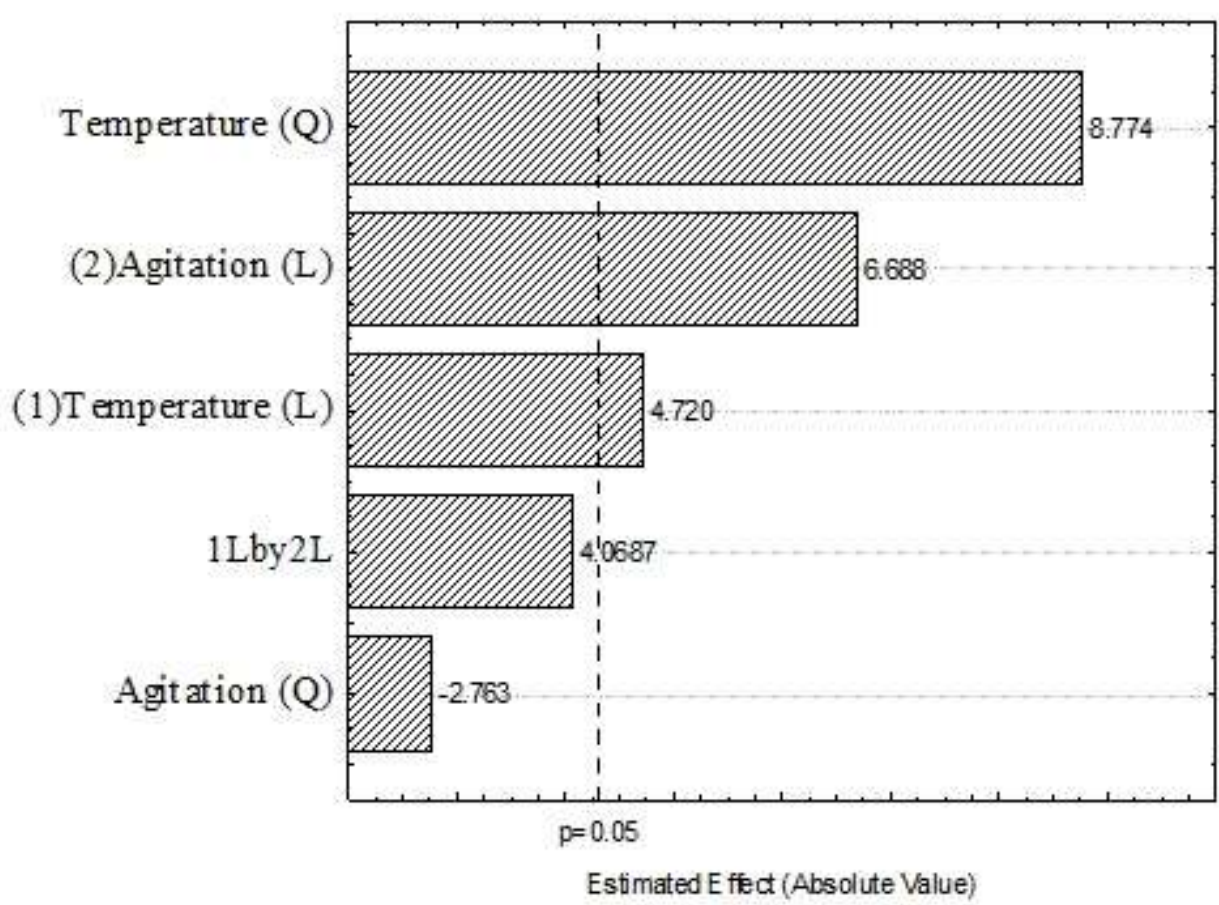

Figure 2. Temperature and agitation estimated effects for xylanase extraction.

\section{Cellulolytic Extracts Partial Characterization}

The highest xylanase $(463.31 \mathrm{U} / \mathrm{g})$ an; $\mathrm{d}$ avicelase $(27.31 \mathrm{U} / \mathrm{g})$ activity values were obtained at $50^{\circ} \mathrm{C}$ and $\mathrm{pH} 5.3$ as per activity determination conditions (Table 3 ).

Table 3. $2^{2}$ full factorial design matrix of $\mathrm{pH}$ and temperature on xylanase and avicelase activity determination.

\begin{tabular}{ccccc}
\hline Assays & \multicolumn{2}{c}{ Independent Variables } & $\begin{array}{c}\text { Xylanase } \\
(\mathbf{U} / \mathbf{g})\end{array}$ & $\begin{array}{c}\text { Avicelase } \\
\mathbf{( U / g )}\end{array}$ \\
\cline { 2 - 3 } & $\mathbf{X}_{\mathbf{1}}$ & $\mathbf{X}_{\mathbf{2}}$ & 158.30 & 2.6 \\
1 & $-1(4.3)$ & $-1(40)$ & 312.22 & 1.03 \\
2 & $1(6.3)$ & $-1(40)$ & 155.06 & 3.21 \\
3 & $-1(4.3)$ & $1(60)$ & 274.63 & 2.42 \\
4 & $1(6.3)$ & $1(60)$ & 74.61 & 1.69 \\
5 & $-1.41(3.9)$ & $0(50)$ & 323.95 & 3.52 \\
6 & $1.41(6.7)$ & $0(50)$ & 314.64 & 6.14 \\
7 & $0(5.3)$ & $-1.41(36)$ & 104.07 & 9.85 \\
8 & $0(5.3)$ & $1.41(64)$ & 463.31 & 27.31 \\
9 & $0(5.3)$ & $0(50)$ & 425.73 & 24.46 \\
10 & $0(5.3)$ & $0(50)$ & 444.52 & 23.45 \\
\hline 11 & $0(5.3)$ & $0(50)$ & &
\end{tabular}

$\mathrm{X}_{1}=\mathrm{pH} ; \mathrm{X}_{2}=$ temperature $\left({ }^{\circ} \mathrm{C}\right)$.

Statistical analysis allowed contour curves construction (Fig. 3), confirming temperature and $\mathrm{pH}$ optimization for both enzymes activity, which were similar to the conditions optimized by other researchers using different microorganisms [19,23,27]. 


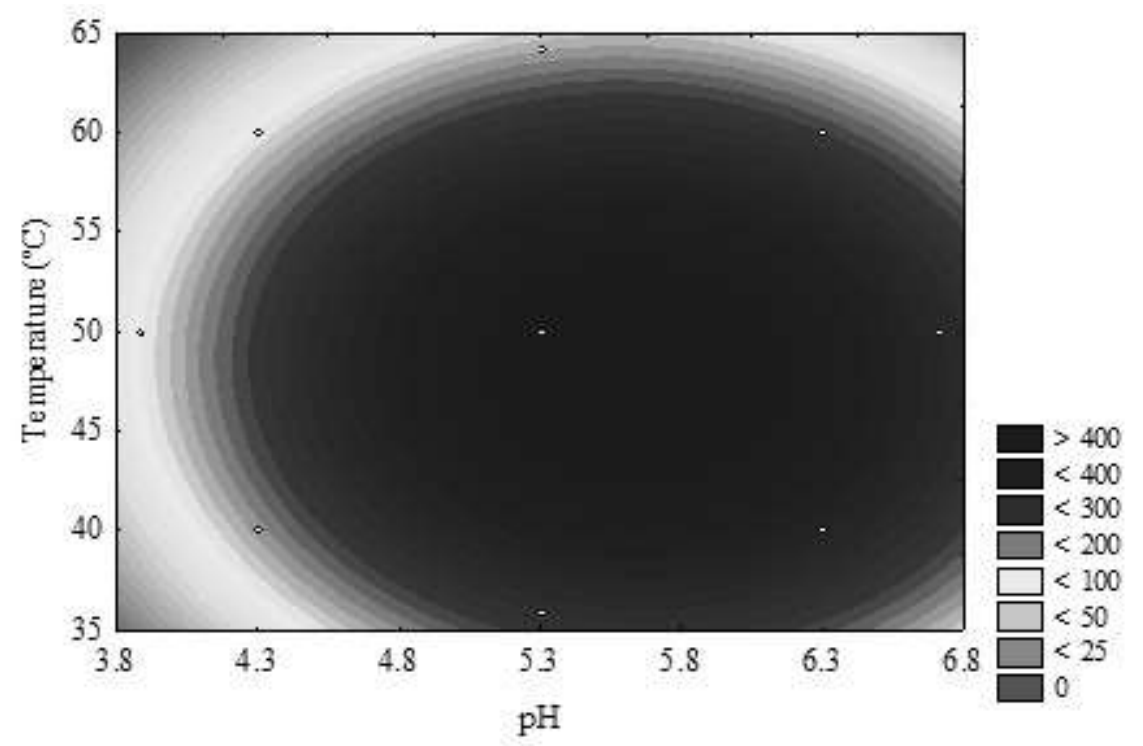

(a)

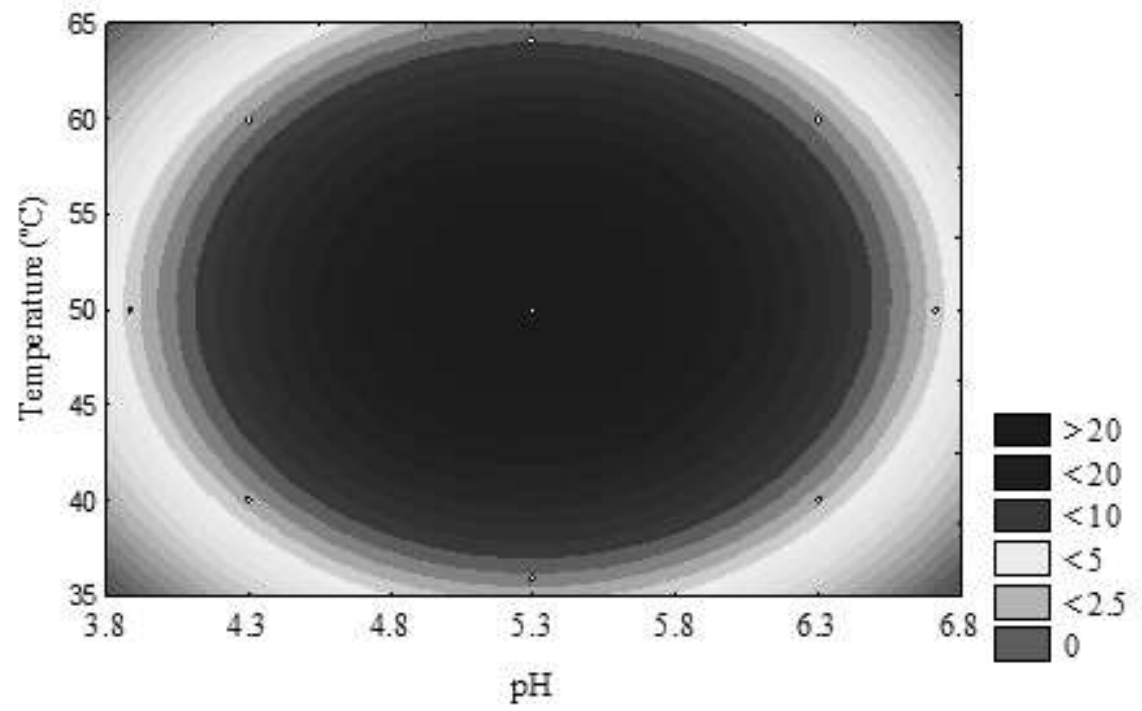

(b)

Figure 3. Contour curves indicating temperature and $\mathrm{pH}$ influence on xylanase activity (a) and avicelase (b) determination.

In relation to stability at different $\mathrm{pH}$ values, xylanase and avicelase showed higher stability between 4.5 and 5.5 , that is, about $50 \%$ activity reduction after 108 and $144 \mathrm{~h}$, respectively (Fig. 4). 


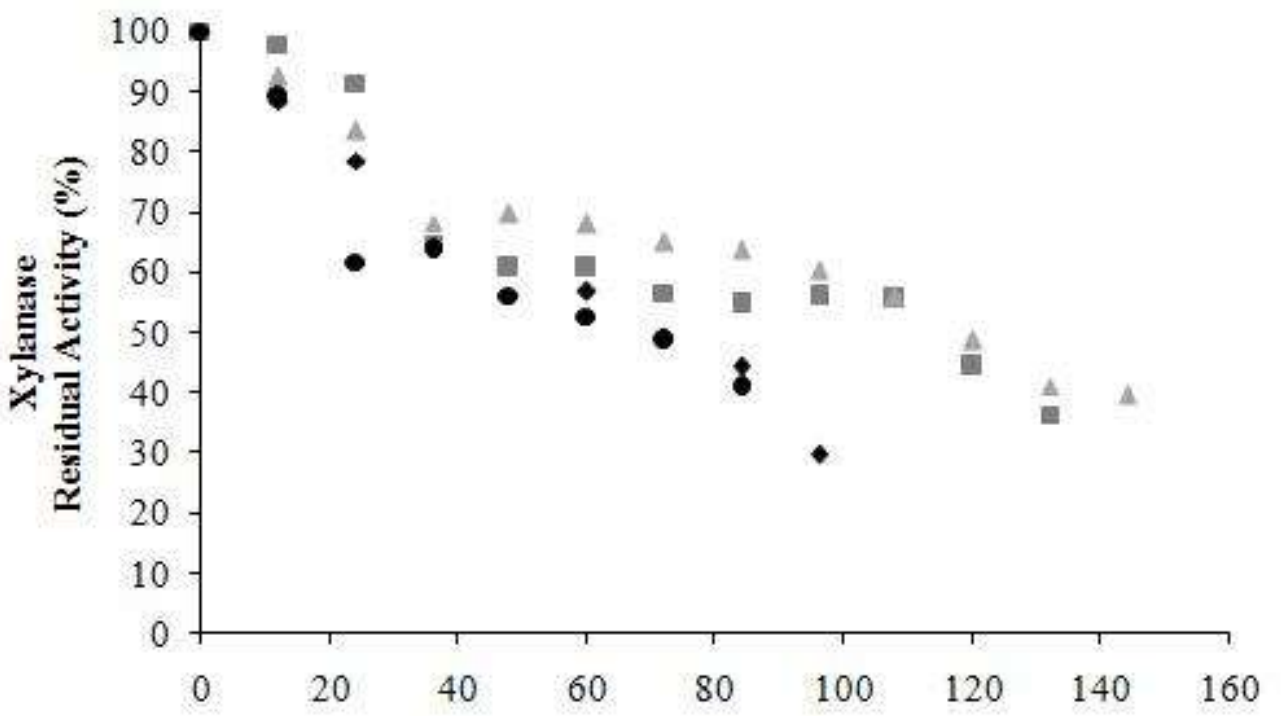

Time (h)

$\bullet \mathrm{pH} 3.5$

$\mathrm{mH} 4.5$

$\triangle \mathrm{pH} 5.5$

$\bullet \mathrm{pH} 6.5$

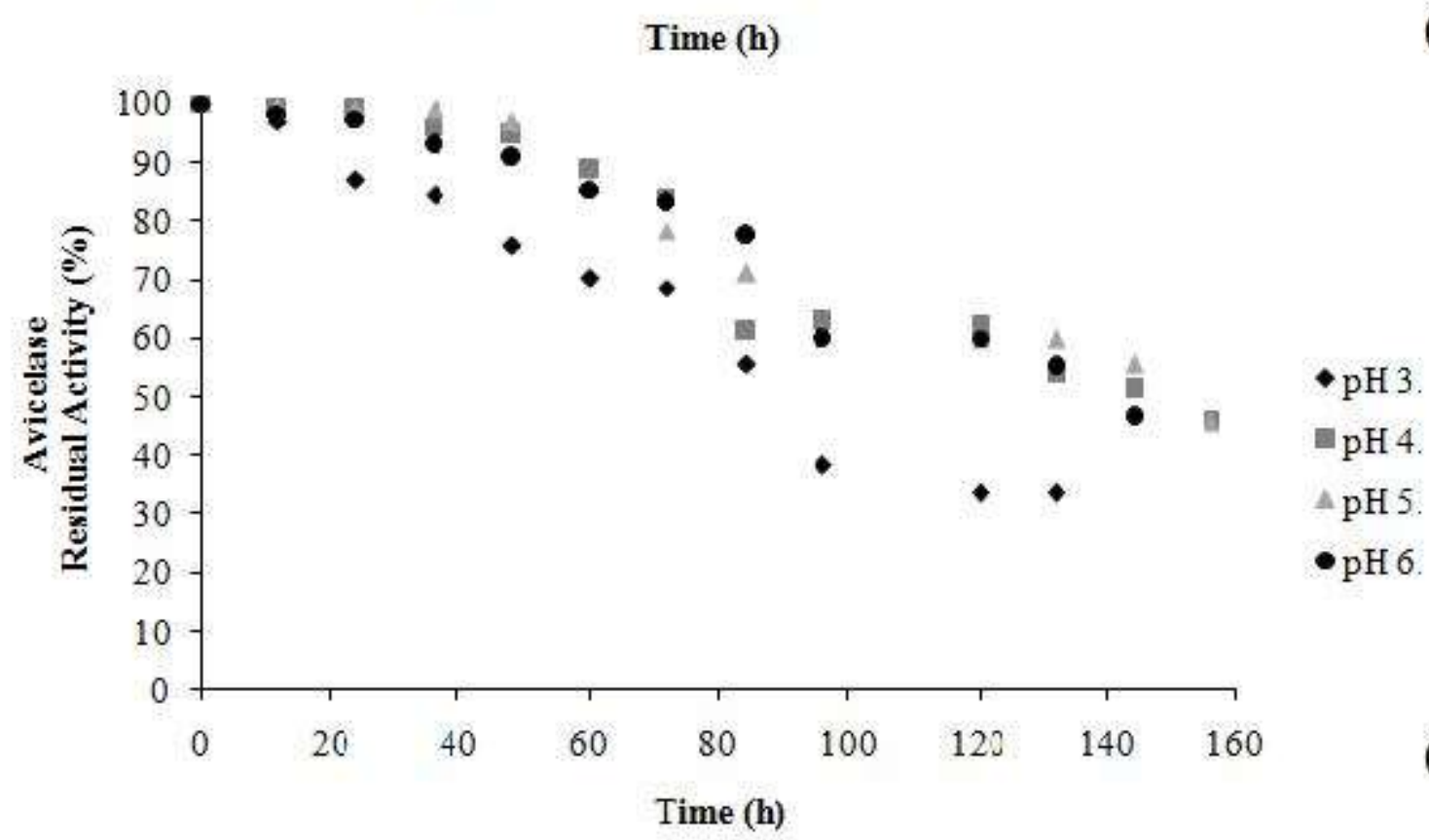

(a)

(b)

Figure 4. Cellulolytic enzymes xylanase (a) and avicelase (b) stability at different pH levels.

Regarding stability at storage temperature, xylanase maintained approximately $80 \%$ residual activity for up to $60 \mathrm{~h}$ at $25^{\circ} \mathrm{C}$ and $70 \%$ for up to $40 \mathrm{~h}$ storage at $40^{\circ} \mathrm{C}$. Xylanase enzyme residual activity reduction (about 50\%) was observed after $108 \mathrm{~h}$ reaction (Fig. 5a) at both temperatures. This stability time was similar to or even higher than that obtained with other enzymatic extracts presented in the literature $[23,28]$. Avicelase residual activity reached about $50 \%$ at 144 and $96 \mathrm{~h}$, stored at 25 and $40^{\circ} \mathrm{C}$, respectively (Fig. $5 b)$, with a linear residual activity reduction as a function of storage time. Drastic activity losses for both enzymes were observed at 50,60 and $70^{\circ} \mathrm{C}$ causing enzyme deactivation in a short period of time (Fig. 5a and b).

Both enzymes, at low temperatures, showed a linear residual activity reduction in relation to storage time (Fig. 5). However, xylanase presented higher thermal stability (residual activity over $50 \%$ after more than 160 days storage) (Fig. $5 \mathrm{c}$ ) in comparison to avicelase (50\% residual activity reduction after 40 days storage) (Fig. $5 \mathrm{~d}$ ). Storage at $-20^{\circ} \mathrm{C}$ showed a significant difference from that under refrigeration $\left(4^{\circ} \mathrm{C}\right)$ for xylanase, but not for avicelase. Most studies found in the literature only evaluated avicelase stability at high temperatures, which presents lower stability $[27,29-31]$ than that obtained in the present study. 

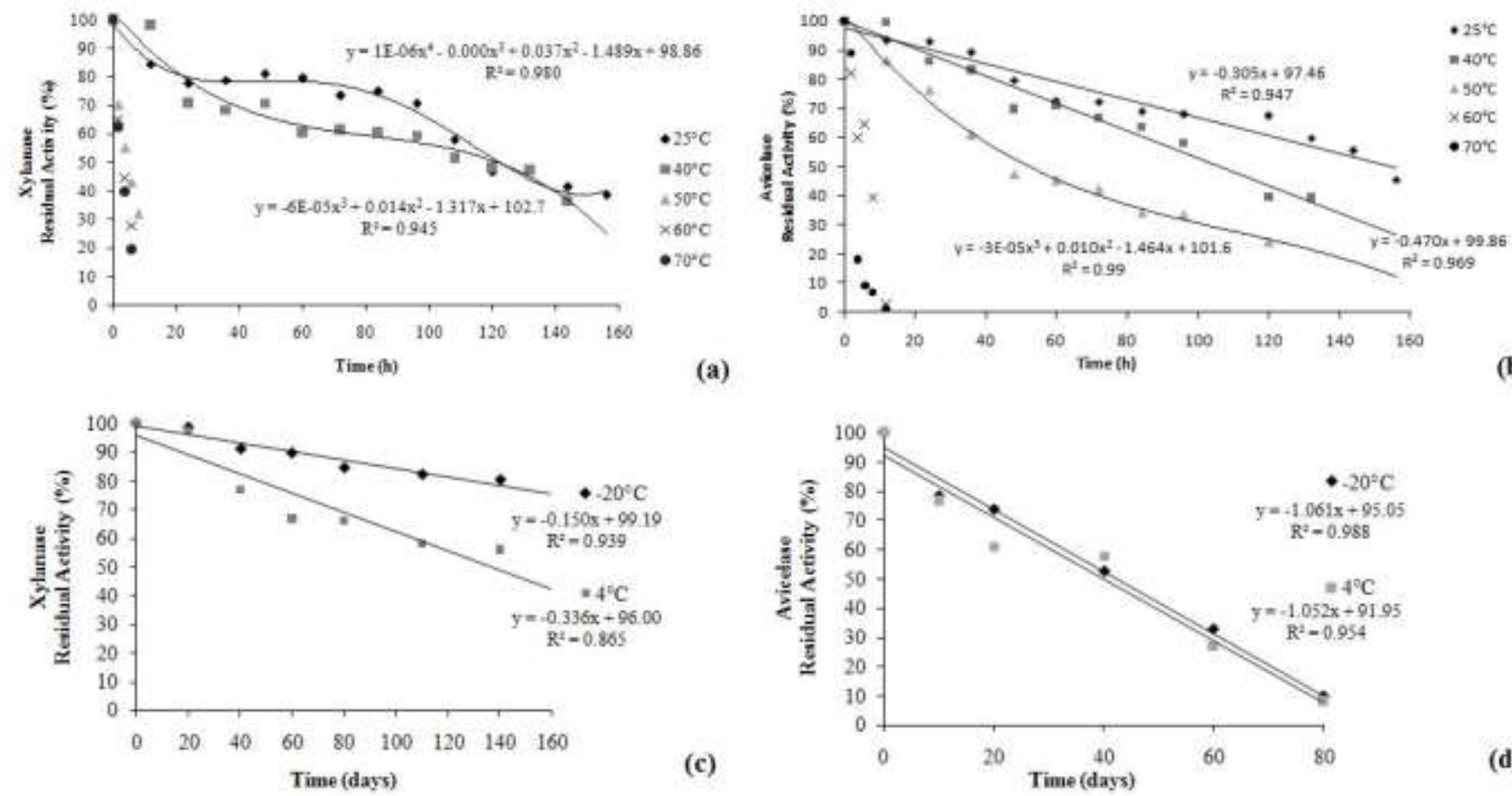

(b)

Figure 5. High temperatures enzymatic stability influence on xylanase (a) and avicelase (b) and low temperatures on xylanase (c) and avicelase (d).

Half-life $\left(t_{1 / 2}\right)$, kinetic thermal denaturation constant $(K d)$, and $D$-value for different enzymes are shown in Table 4. Half-life and decimal reduction (D) times of a biocatalyst correspond to values that are numerically equal to the time required to achieve $50 \%$ and $10 \%$ decrease in its initial enzymatic activity, respectively.

Table 4. Experimental $k_{d}, t_{1 / 2}$, D, Ed and $Z$ values for xylanase and avicelase, as a temperature function.

\begin{tabular}{|c|c|c|c|c|c|}
\hline $\begin{array}{c}\text { Temperature } \\
\left({ }^{\circ} \mathrm{C}\right)\end{array}$ & $K_{d}\left(\min ^{-1}\right)$ & $t_{1 / 2}(h)$ & $\begin{array}{c}\text { D Value } \\
\text { (min) }\end{array}$ & Ed (KJ/mol/T.K) & $\mathrm{Z}$ Value $\left({ }^{\circ} \mathrm{C}\right)$ \\
\hline \multicolumn{6}{|c|}{ Xylanase } \\
\hline 25 & 0.005 & 138.6294 & 460.517 & \multirow{5}{*}{89.1} & \multirow{5}{*}{22.2} \\
\hline 40 & 0.005 & 138.6294 & 460.517 & & \\
\hline 50 & 0.138 & 5.022806 & 16.6854 & & \\
\hline 60 & 0.209 & 3.316494 & 11.01715 & & \\
\hline 70 & 0.267 & 2.596057 & 8.623914 & & \\
\hline \multicolumn{6}{|c|}{ Avicelase } \\
\hline 25 & 0.004 & 173.286 & 575.646 & \multirow{5}{*}{96.7} & \multirow{5}{*}{20.4} \\
\hline 40 & 0.006 & 115.524 & 383.764 & & \\
\hline 50 & 0.011 & 63.013 & 209.326 & & \\
\hline 60 & 0.279 & 2.484 & 8.253 & & \\
\hline 70 & 0.381 & 1.819 & 6.044 & & \\
\hline
\end{tabular}

Temperature increase affected the enzymes' thermal deactivation process evaluated with similar inactivation rates $\left(\mathrm{K}_{\mathrm{d}}\right)$ between xylanase and avicelase at different temperatures. Avicelase was more stable at thermal deactivation than xylanase, with half-life times and $D$ values ranging from 173.29 to 63.01 $\mathrm{h}$ and 575.65 to $209.33 \mathrm{~min}$ at temperatures from 25 to $50^{\circ} \mathrm{C}$. Xylanase showed stability only up to $40^{\circ} \mathrm{C}$, and both showed strong thermal deactivation at higher temperatures. Such high parameters values are desirable during industrial operations since they ensure an enzyme more resistant to deactivation caused by temperature effects ${ }^{32}$.

The 22.2 and $20.4 \mathrm{Z}$ values (Table 4) indicated that a change in these temperature ranges would generate one logarithmic cycle reduction on xylanase and avicelase enzymatic activities, respectively.

Driss and coauthors [33] used Penicillium occitanis for xylanase enzyme bioproduction, obtaining a 729.6, 420, and $115.5 \mathrm{~h}$ for half-life and $0.00095,0.00165$ and 0.00600 for thermal denaturation kinetic 
constant $\left(\mathrm{K}_{\mathrm{d}}\right)$ at 50,60 and $70^{\circ} \mathrm{C}$. Such values were higher than those found in the present study. Zanin and coauthors [34] obtained 0.0492 and 4.1678 for $K_{d}$; and 14.1 and 0.17 for $t_{1 / 2}$, respectively at 60 and $70^{\circ} \mathrm{C}$, using $A$. niger on cellobiose substrate. No data were found in the literature regarding deactivation energy and $Z$ value for avicelase produced by Penicillium sp.

For enzymatic processes, besides thermal deactivation studies, thermodynamic parameters determination is also needed to elucidate the molecules behavior against enzymatic inactivation under different physiological conditions, as well as the effects of temperature on the enzymatic deactivation rate [35].

Arrhenius linearization was used to represent enzymatic activity variation as a function of enzymatic denaturation kinetic constants $\left(K_{d}\right)$ at different temperatures $(1 / T)$. $E_{d}$ value for xylanase $(89.1 \mathrm{~kJ} / \mathrm{mol})$ was slightly lower than for avicelase $(96.7 \mathrm{~kJ} / \mathrm{mol})$, corroborating with the higher thermostability for avicelase. Different authors found variable $E_{d}$ values for xylanase obtained with enzymatic extracts from different isolates. Driss and coauthors [33] using $P$. Occitanis immobilized to increase digestibility in broiler ration, found an $E_{d}$ value of $83.02 \mathrm{~kJ} / \mathrm{mol}$ for immobilized xylanase. Balsan and coauthors [36] found $E_{d}$ value of $177.6 \mathrm{~kJ} / \mathrm{mol}$ for enzyme cellulase from $T$. reesei (NS 50013) in lignocellulolytic culture media. Zanin and coauthors [34], using $A$. niger on cellobiosis substrate, obtained $80.6 \mathrm{Kcal} / \mathrm{mol}$ values for thermal deactivation energy in free enzyme.

\section{CONCLUSION}

This work obtained xylanase and avicelase bioproduction by a new isolated Penicillium sp. in solidstate fermentation, using soybean hulls as substrate that presented maximized activity for xylanase and avicelase $\left(435.35\right.$ and $23.73 \mathrm{U} / \mathrm{g}$,) with $30^{\circ} \mathrm{C}, 1 \times 106$ spores/g substrate, at 14 and 7 fermentation days with 70 and $76 \%$ substrate moisture, respectively. The citrate buffer solution $(0.05 \mathrm{M}, \mathrm{pH} 4.5)$, at $60^{\circ} \mathrm{C}$ and 175 rpm or $50^{\circ} \mathrm{C}$ and $125 \mathrm{rpm}$ for xylanase or avicelase, respectively, showed better activity results, 430.77 and $26.77 \mathrm{U} / \mathrm{g}$. The optimum $\mathrm{pH}$ and temperature for enzymatic activity determination were 5.3 and $50^{\circ} \mathrm{C}$ for both enzymes studied. The avicelase was more stable for thermal deactivation than xylanase, presenting the half-life times and D values ranging from 173.29 to $63.01 \mathrm{~h}$ and 575.65 to $209.33 \mathrm{~min}$ from 25 to $50^{\circ} \mathrm{C}$, respectively. However, the half-life times and $D$ values for xylanase ranged from 138.63 to $5.02 \mathrm{~h}$ and from 460.52 to $16.68 \mathrm{~min}$, respectively, at the same temperature range. $Z$ values for xylanase and avicelase were 22.2 and 20.4 , respectively. Ed value for xylanase $(89.1 \mathrm{~kJ} / \mathrm{mol})$ was slightly lower than for avicelase $(96.7 \mathrm{~kJ} / \mathrm{mol})$, indicating higher thermostability for avicelase. Finally, the production of xylanase and avicellase in agroindustrial substrate allows the reduction of the cost of these, generating attention from the industrial point of view, mainly as a resource for the biofuel industry, animal feed, food, textile and detergent.

Acknowledgments: The authors would like to thank CAPES, CNPq, and FAPERGS for their financial support.

Conflicts of Interest: The authors declare no conflict of interest.

\section{REFERENCES}

1. Keshwani DR, Cheng JJ. Switchgrass for bioethanol and other value-added applications: A review. Biores Technol. 2009 Feb;100(4):1515-23.

2. Singhania RR, Sukumaran RK, Patel AK, Laroche C, Pandey A. Advancement and comparative profiles in the production technologies using solid-state and submerged fermentation for microbial cellulases. Enzyme Microb Technol. 2010 Jun;46(7):541-9.

3. Azzaz HH, Murad HA, Kholif AM, Hanfy MA, Abdel Gawad MH. Optimization of culture conditions affecting fungal cellulose production. Res J Microbiol. 2012 Jan;7:23-31.

4. Polizeli MLTM, Rizzatti ACS, Monti R, Terenzi HF, Jorge JA, Amorim DS. Xylanases from fungi: properties and industrial applications. Appl Microbiol Biotechnol. 2005 Jul;67(5):577-91.

5. Gírio FM, Fonseca C, Carvalheiro F, Duarte LC, Marques S, Bogel-Lukasik R. Hemicelluloses for fuel ethanol: A review. Biores Technol. 2010 Jul;101(13):4775-800.

6. Filho EXF. Xilanases. In: Said S, Pietro R, editors. Enzimas como Agentes Biotecnológicos. Ribeirão Petro: Legis Summa Ltda. 2004. p.137-148.

7. Zanoelo FF, Polizeli MLTM, Terenzi HF, Jorge JA. Purification and biochemical properties of a thermostable xylose-tolerant $\beta$-D-xylosidase from Scytalidium thermophilum. J Ind Microbiol Biotechnol. 2004 May;31(4):170-6. 
8. Lee JW, Park JY, Kwon M, Choi IG. Purification and characterization of a thermostable from the brown-rot fungus Laetiporus sulphureus. J Biosci Bioeng. 2009 Jan;107(1):33-7.

9. Wood TM, Bhat KM. Methods for measuring cellulose activities. Method Enzymol. 1988;160:87-112.

10. Chandra GS, Reddy BR. Exoglucanase production by Aspergillus niger grown on wheat bran. Ann Microbiol. 2013 Sep;63(3):871-7.

11. Ray RR. Microbial avicelase: An overview. Bull Enviro Pharmacol Life Sci. 2015 Mar;4(4):3-13.

12. Pithadiya D, Nandha DE, Thakkar A. Partial purification and optimization of xylanase from Bacillus circulans. Arch Appl Sci Res. 2016;8(2):1-10.

13. Suleman M, Bukhari IH, Aujla MI. Production and characterization of xylanase from Aspergillus niger using wheat bran, corn cobs, and sugar cane bagasse as carbon sources with different concentrations. Bioresour Technol. 2016 Jan;3(1):1-9.

14. Ghazala I, Haddar A, Romdhane MB, Ellouz-Chaanouni S. Screening and molecular identification of new microbial strains for production of enzymes of biotechnological interest. Braz Arch Biol Technol. 2016 Jun;59:112.

15. De Bortoli V, Griebeler NE, Astolfi AL, Daronch NA, Shumann AC, Salazar LN, Cansian RL, Backes GT, Zeni J. Seleção de fungos filamentosos produtores de amilases, proteases, celulases e pectinases (Selection of filamentous fungi producing amylases, proteases, cellulases and pectinases). Ver Acad Ciencia Anim. 2015 Jan;13:15-24.

16. Dhillon GS, Brar SK, Kaur S, Metahni S, M'Hamdi N. Lactoserum as a moistening medium and crude inducer for fungal cellulase and hemicellulase induction through solid-state fermentation of apple pomace. Biomass Bioenerg. 2012 Jun;41:165-74.

17. Borszcz V, Boscato TRP, Antunes A, Zeni J, Backes GT, Valduga E. Cultivation of Agro-Industrial Residues. Ind Biotechnol. 2017 Jun;13(3):141-8.Recovery of Pectinase Obtained by Solid-State

18. Miller GL. Use of dinitrosalisylic acid reagent for determination of reducin sugar. Anal. Chem. 1959;31:426-428.

19. Maki M, Leung KT, Qin W. The prospects of cellulase-producing bacteria for the bioconversion of lignocellulosic biomass. Int J Biol Sci. 2009 Feb;5(5):500-16.

20. Kim DM, Ji Cho E, Kim JW, Lee YW, Chung HJ. Prodution of cellulases by Penicillium sp. in a solid-state fermentation of oil palm empty fruit bunch. Afr J Biotechnol. 2014 Jan;13(1):145-55.

21. Deswal D, Khasa YP, Kuhad RC. Optimization of cellulase production by a brown rot fungus Fomitopsis $\mathrm{sp}$. RCK2010 under solid state fermentation. Bioresour Technol. 2011 May;102(10):6065-72.

22. Ghoshal G, Banerjee UC, Chisti Y, Shivharea US. Optimization of Xylanase Production from Penicillium citrinum in Solid-State. Chem Biochem Eng Q. 2012 Mar;26(1).61-9.

23. Astolfi V. Cellulase and hemicellulase production by solid state fermentation using Trichoderma reesei NRRL 3652 in agroindustrial residues [master's thesis]. Erechim (RS): Universidade Regional Integrada do Alto Uruguai e das Missões; 2014. 130p.

24. Pirota RDPB, Tonelotto M, Delabona PS, Tremacoldi CR,Farinas CS. Caracterização de fungos isolados da região Amazônica quanto ao potencial para produção das enzimas envolvidas na conversão da biomassa vegetal (Characterization of isolated fungi of the Amazon region regarding the potential for the production of the enzymes involved in the conversion of plant biomass). Cienc Rural. 2015 Set;45(9):1606-12.

25. Mamma D, Kourtoglou E, Christakopoulos P. Fungal multienzyme production on industrial by-products of the citrus-processing industry. Bioresour Technol. 2008 May;99 (7):2373-83.

26. Pereira JC, Marques NP, Rodrigues A, Oliveira TB, Boscolo M, Silva R, et al. Thermophilic fungi as new sources for production of cellulases and xylanases with potential use in sugarcane bagasse saccharification. J App Microbiol. 2015 Apr;118(4):928-39.

27. Kuo HW, Zeng JK, Wang PH, Chen WCA. A Novel Exo-Glucanase Explored from a Meyerozyma sp. Fungal Strain. Adv Enzyme Res. 2015 Jan;3(3):53-65.

28. Falkoski DF, Guimarães VM, Almeida MN, Alfenas AC, Colodette JL, Rezende ST. Chrysoporthe cubensis: A new source of cellulases and hemicellulases to application in biomass saccharification processes. Bioresour Technol. 2013 Feb;130:296-305.

29. Makky EA. Avicelase Production by a Thermophilic Geobacillus stearothermophilus Isolated from Soil using Sugarcane Bagasse. World Acad Sci Eng Technol. 2009 Jan; 57 (3): 487-91.

30. Gomathi D, Muthulakshmi C, Guru Kumar D, Ravikamur G, Kalaiselvi M, Uma C. Submerged fermentation of wheat bran by Aspergillus flavus for production and characterization of carboxi methyl cellulose. Asian Pac J Trop Biomed. 2012 Jan;2(1):S67-S73. 
31. Mihajlovski KR, Carevic MB, Devic MLJ, Siler-Marinkovic S, Rajilic-Stojanovic MD, Dimitrijevic-Brankovic S. Lignocellulosic waste material as subtract for avicelase production by new strain of Paenibacillus chitinoiliticus CKS1. Int Biodeter Biodegr. 2015 Oct;104:426-34.

32. De Castro SR, Ohara A, Nishide T, Albernaz J, Soares M, Sato H. A new approach for proteases production by Aspergillus niger based on the kinetic and thermodynamic parameters of the enzymes obtained. Biocatal Agric Biotechnol. 2015 Apr;4(2):199-207.

33. Driss D, Driss Z, Chaaril F, Chaabouni SE. Immobilization of His-tagged recombinant xylanase from Penicillium occitanis on Nickel-chelate Eupergit C for increasing digestibility of poultry feed. Bioengineered. 2014 Jul;5(4):274-9.

34. Zanin G, Santana C, Bon E, Giordano R, De Moraes F, Andrietta SR, et al. Brazilian bioethanol program. Appl Biochem Biotechnol. 2000;84-86:1147-61.

35. Heidtmann RB, Duarte SH, Pereira LP, Braga ARC. Caracterização cinética e termodinâmica de $\beta$-galactosidase de Kluyveromyces marxianus CCT 7082 fracionada com sulfato de amônio (Kinetic and thermodynamic characterization of $\beta$-galactosidase from Kluyveromyces marxianus CCT 7082 fractionated with ammonium sulfate). Braz J Food Technol. 2012;15(1):41-9.

36. Balsan G, Astolfi V, Benazzi T, Meireles MA, Maugeri F, Di Luccio M, et al. Characterization of a commercial cellulase for hydrolysis of agroindustrial substrates. Bioproc Biosyst Eng. 2012 Mar;35:1229-37.

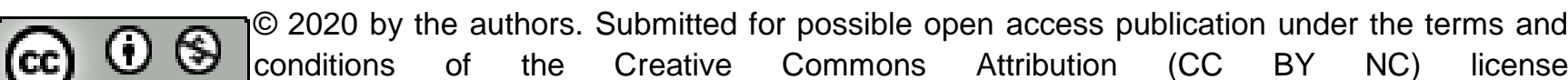
EY NC (https://creativecommons.org/licenses/by-nc/4.0/). 